\title{
Promoting Cultural Identity Through Arts Education: The Indonesian Context
}

\author{
Sofyan Salam* \\ Universitas Negeri Makassar \\ sofyansal@unm.ac.id
}

\begin{abstract}
Cultural identity is a challenging issue faced by developing countries today. Globalization which presents a strong and aggressive culture, called "Global Culture," is considered by many cultural observers a threat to the existence of local cultures in developing countries. This unfortunate because these local cultures play a crucial role in the development of a country's cultural identity. Because cultural identity is necessary for showing the existence of a country in international relations, various efforts are made to promote that cultural identity. One effort to promote cultural identity that is considered potential is through arts education in general public schools and arts (visual art and performing art) schools/colleges. Arts education to promote cultural identity recommended in this paper utilizes local cultures as a source of inspiration. This paper presents three examples of such arts learning strategies. This paper also identifies things that can hamper the implementation of arts learning strategies to promote cultural identity in order to provide a more comprehensive picture.
\end{abstract}

Keywords-cultural identity, arts education, globalization, local culturals

\section{INTRODUCTION}

In the Indonesian context, the issue of identity is not new. During the Dutch colonial era, the issue had become a subject of discussion among the Indonesian freedom fighters. The establishment of Taman Siswa schools by Ki Hadjar Dewantoro was to build national identity through the cultivation of students' cultural awareness. Ki Hadjar Dewantoro realized that the Indonesian people needed to be encouraged to free themselves from the shackles of colonialism. This encouragement can be done through education that builds students' self-esteem as individuals with dignity and unique identity. Similar to the Taman Siswa school, INS (Indonesische Nederland School) which was founded by Mohammad Sjafei in Kayutanam, WestSumatera, also offered educational programs to develop student cultural awareness. In the early years of Indonesian independence, Soekarno, the first president of the Republic of Indonesia, intensively introduced the idea of Berdikari (stand on one's own feet) which means sovereign in politics, independent in economics, and personality in culture. The Constitution of the Republic of Indonesia reflects the desire to develop Indonesia's national identity. Article 32 of the Constitution states that "the Government shall develop the National Culture of Indonesia."

Today the issue of identity is certainly no longer the same as in colonial times and in the early years of Indonesian independence. Since the proclamation of Indonesian independence on August 17, 1945, the
Indonesian people have become politically independent and are free to determine their destiny. The feeling of being politically colonized is gone. In the early years of Indonesian independence, the issue of national identity revolved around how to formulate "the national culture of Indonesia." This was resolved by the formulation of the definition of Indonesian culture as can be seen in the explanation of Article 32 of the Constitution of Republic of Indonesia as follows:

\begin{abstract}
"National culture is the culture that emerges as a product of the minds of all the Indonesian peoples. Earlier and indigenous cultures as represented by the local cultures all over Indonesia are a definite part of national culture. Cultural endeavours shall be aimed at developing civilization, culture, and (national) unity, without denying novel elements from foreign cultures which may develop or enrich national culture as such and improve the human dignity of the Indonesian nation" (Soebadio, 1985: 18)
\end{abstract}

Although the constitution has formulated the term "national culture of Indonesia," discussions on this term continue. The emergence of new challenges related to national culture issues that require the attention of stakeholders is the cause of ongoing discussions.

\section{GLOBALIZATION AND CULTURAL IDENTITY}

One of the issues related to identity faced by Indonesian people today, which is discussed in this paper, is how to deal with new challenges that are no less difficult, namely challenges that arise as a result of globalization. Globalization that is happening in the 21 st Century, which can be called "contemporary globalization," is the result of advances in information, communication, and transportation technology. These technological advances, unprecedented before, allow the widespread and rapid dissemination of information as facilitated by the internet and cable TV as well as the development of an effective and efficient international transportation system. This contemporary globalization has given birth to a new global culture that challenges the existence of local cultures, as the unique identity of developing countries.

Castells (2010: 89), a sociology and planning professor, notes that ini recent decades two parallel processes have taken place at the word level namely globalization on one hand, and the reaffirmation of various cultural identities (religious, national, ethnic, and other specific identities), on the other. These two processes are 
interrelated. Globalization defined by Albrow and King (Cuterela, 2012: 138) as " all the processes by which people in the world are incorporated into a single world society" is seen as a form of cultural hegemonization that triggers the reaffirmation of various cultural identities.

Cultural observers often label globalization as Westernization or Americanization due to the dominant role of the developed countries (Western nations, especially the United States) in the global arena. This labelling makes globalization a threat to the preservation of local cultures of small countries. Wangboje, a scholar from Nigeria, (1995:193) equates globalization as cultural imperialism. He reminds us that this cultural imperialism will force local cultures to adapt to the standard and values of developed nations in order to survive. Because local cultures must adapt themselves to survive, local cultures in small countries will slowly but surely lose their identity. The threat of losing cultural identity, as stated by Wangboje above, is a common phenomenon that we can see everywhere, especially in developing countries. That is why Mustafa KOC (2006: 37) and Wangboje (1995:196) blame globalization for causing cultural crises in various parts of the world.

Culturalists put forward various thoughts to overcome the challenges of globalization concerning cultural identity. One of these thoughts is that local culture as a symbol of identity should not be rigid but dynamic and ready to adapt intelligently. This kind of thinking had been applied in Indonesia as revealed in Cultural Policy in Indonesia published 34 years ago, as follows: " ...the Indonesian have shown a remarkable ability to adapt foreign influence in such a way that something new is created that is found nowhere else and differs considerably from the original influence. This ability has been called 'local genius'... (Soebadio, 1985: 11). Thus, the meaning of cultural identity in this context is flexible and dynamic as stated by Hall (1990: 225) that cultural identity is a matter of 'becoming' as well as of 'being.' It belongs to the future as much as to the past." Cultural identity seems to be constantly changing throughout the ages following social and cultural developments.

From the description above, the relevant question about the relationship between globalization and local cultures is "what contribution can local cultures make to global culture? The attitude needed to answer this question is to see globalization not only as a threat but also as an opportunity for local cultures to show their existence.

\section{THE POTENTIAL OF ARTS EDUCATION IN PROMOTING CULTURAL IDENTITY}

Arts education has become an essential part of the school curriculum since the introduction of the formal education system in Indonesia. Educational policymakers in Indonesia realize that arts education is very much needed in the education and development of young people. Regarding the importance of arts education in the school curriculum, Eisner (1997:9) writes: "The prime value of the arts in education lies, in my point of view, in the unique contributions it makes to the individual's experience with and understanding of the world. Tal (2016: 3) categorizes arts education as cultural education which should be an important part of the younger generation. He reminds us that: "A society that takes children and young people seriously provides them with a good cultural education (in the visual arts, dance, drama and music, media, literature and heritage) and ensures that it is universally accessible."

As a form of cultural education, arts education has the potential to promote cultural identity because it provides broad opportunities for students to (1) learn about traditions and cultural heritage. This learning is a means to connect young people with traditions and cultural heritage that is useful to make them aware of preserving and revitalizing these traditions and cultural heritage so that they remain relevant to the needs of present and future generations. This, of course, fosters historical and cultural awareness that is indispensable in promoting identity, tolerance and mutual understanding; (2) develop their interests and artistic talents. Engagement with arts helps students to develop skills in expressing their thoughts and feelings, and to be more aware of various point of view, that there are many ways to see things and there are many possible solutions to solve a problem. Such creative experiences facilitate students to explore matters relating to personal, social, and cultural identity, and (3) make sound judgements in a variety of arts learning contexts. Making good judgement is an important skill needed by students in dealing with various actual problems in life, including issues of cultural identity.

\section{ARTS-LEARNING STRATEGIES THAT CAN PROMOTE CULTURAL IDENTITY}

Arts-learning centres on activities that facilitate students in understanding, creating, and appreciating arts works (visual-art, dance, music, theatre). These learning activities may be categorized as conceptual, productive, and critical aspects of arts learning. Thus, promoting cultural identity through arts learning is conducted by integrating cultural issues with conceptual, productive, and critical aspects of arts learning. The following are examples of artslearning strategies for promoting students' cultural identity.

\section{Example No. 1}

- Arts Discipline: Visual Art

- Level: elementary school/Highschool/visual-art college

- Learning activity: visual-art making (productive)

- The topic of Learning activity: Creating works of art using artistic approaches, ornamental motifs, and techniques typical of local traditional arts.

- Rationale: Promoting cultural identity through visual-art learning can be done by allowing students to explore the local-culture (local traditional art) that belongs to them. In this context, local traditional arts have a special role in developing a sense of self-identity of students. Exploring local traditional arts can promote cultural identity because it provides opportunities for students to express their feelings through the use of the artistic approaches, ornamental motifs, 
and techniques typical of local traditional arts that belong to their own culture. The product of this learning is local traditional artworks created by students which also reflect the local cultural identity. Of course, the topic of learning activities must be following the level of student maturity. For example, at the elementary school level, the art of traditional paper cutting is appropriate, and for the visual art college level, traditional woodcarving is suitable.

- Learning strategies: (1) Provide opportunities for students to explore selected local traditional art forms; (2) Teach students about the common characteristics of Indonesian traditional arts; (3) Ask students to make a work of visual art individually using an artistic approach, ornamental motifs, and techniques of a selected local traditional art form; (4) Ask students to discuss the uniqueness of the artistic approach, ornamental motifs, and techniques of the selected local traditional art; (5) Motivate students to be proud of their own culture.

\section{Example No. 2}

- Arts Discipline: Dance

- Level: Vocational high school/dance college

- Learning activity: Composing dance/choreography (productive)

- The topic of Learning activity: Composing contemporary dance using local traditional dance elements.

- Rationale: Promoting cultural identity through dance learning can be done by allowing students to compose contemporary dance by using local traditional dance elements (theme, movement, music, property, stage setting, and costume). The learning activity of composing contemporary dance follows four main steps, namely: exploration, improvisation, development, and composition. This learning activity allows students to create a contemporary dance that is distinctive due to the use of elements of traditional local dance. This is an example of a learning experience that develops students' cultural competence, that is, competencies in producing cultural products that reflect identity.

- Learning strategies: (1) Provide opportunities for students to explore selected local traditional dance forms. In this exploration step, ask students to identify elements of traditional dance that will be used in composing new contemporary dances; (2) Ask students to conduct dance experiments using elements of the chosen traditional dance; (3) When students are satisfied with the experiment, Ask students to develop parts of the dance (4) Ask students to start putting together parts of the dance into a complete dance; (5) Remind students that the contemporary dances they create are unique because they reflect local culture; (6) Motivate students to be proud of their creation.
Example No. 3

- Arts Discipline: music

- Level: high school/music college

- Learning activity: music appreciation (conceptual/critical)

- The topic of learning activity: Comparing musical works from various traditions

- Rationale: Music learning helps students to understand human experiences, both past and present. It gives students the experience to respect various ways of expressing ideas through music. Such an experience is beneficial in developing students' cultural awareness

- Learning strategies: (1) Give students opportunities to listen to music from various traditions; (2) Explain to students that each piece of music is unique as a reflection of people's beliefs and preferences; (3) Ask students to comment on the uniqueness of the music they have listened to and why?; (4) Motivate students to be proud of Indonesian music traditions.

The three examples of learning strategies above merely outline to be developed further. These examples are expected to inspire teachers in developing arts learning strategies that can promote cultural identity.

\section{CONCLUSION}

In the Indonesian context, promoting cultural identity is an activity that has philosophical and constitutional significance. Philosophically, promoting cultural identity is the answer to the question: "what can Indonesia contribute to enriching global culture?" Constitutionally, promoting cultural identity is an effort to advance Indonesian culture as mandated by the Constitution of the Republic of Indonesia.

One of the ways that is considered a potential to be taken to promote cultural identity is through arts education. Arts education with the conceptual, productive, and critical learning experiences it offers has the potential to develop cultural awareness and cultural competencies that will make students proud of their culture and able to reflect Indonesian culture through their actions. Support from various parties is needed to succeed in the promotion of cultural identity through arts education. The support is necessary because promoting cultural identity through arts education is not always easy to do. Several factors can become obstacles, both external and internal obstacles. The tendency of Indonesians, in general, to admire foreign cultures more than their own culture, is a real obstacle that affects the implementation of arts education in schools. Internal barriers make things worse. Internal barriers found in schools include the limited competence of teachers in implementing meaningful arts education (concerning the promotion of cultural identity), especially at the elementary school level, the limited arts learning facilities in schools, and the low commitment of school administrators to arts/cultural education. Overcoming these barriers is a real 
challenge of promoting cultural identity through arts education in Indonesian schools (Sofyansal@unm.ac.id).

\section{REFERENCES}

Castells, Manuel. 2010. "Globalization and Identity." Quardens de la Mediterrania. 14 p 89-98.

Cuterela, Sandu. 2012. "Globalization: Definition, Processes and Concepts." Revista Romana da Statistica. Trim IV/2012. P $137-$ 146.

Eisner, Elliot W. 1997. Educating artistic Vision. Reston, VA: NAEA

Inac, Husamettin and Feyzullah Unal. 2013. "The Construction of National Identity in Modern Times:Theoretical Perspective." International
Journal of Humanities and Social Science. Vol 3 No 11, June 2013, p 223-232.

Mustafa KOC. 2006. "Cultural Identity Crisis in the Age Of Globalization and Technology."the Turkish Online Journal of Educational Technology, Vol 5 Issue 1 Article 5. January 2006. ISSN: 13036521. P 37-43.

Hall, Stuart. 1990. "Cultural Identity and Diaspora." in Identity, Community, Culture, Difference. Ed. Jonathan Rutherford. London: Lawrence \& Wishart.

Soebadio, Haryati. 1985. Cultural Policy in Indonesia. Paris: Unesco.

Tal, Marlies (Ed). 2016. Basis for Cultural Education: Guide for the Future of School-based and Extra Curricular Cultural Education. Utrecht: LKCA. 